Jurnal Mandala Pharmacon Indonesia, Vol 3.No.2 Desember 2017

Avaiable online at www.jurnal-pharmaconmw.com/jmpi

$p$-ISSN : 2442-6032

$e$-ISSN : 2598-9979

\title{
Formulasi Sabun Pembersih Kewanitaan (Feminime Hygiene) dari Ekstrak Kulit Buah Durian (Durio zibethinus Murray)
}

\author{
Ikka Wahidatul Rahmi1 ${ }^{1}$, Eny Nurhikma1*, Esti Badia1 ${ }^{1}$, Mus Ifaya ${ }^{2}$ \\ ${ }^{1}$ Akademi Farmasi Bina Husada Kendari \\ 2 STIKES Mandala Waluya Kendari
}

\begin{abstract}
ABSTRAK
Sabun pembersih kewanitaan (feminine hygiene) adalah suatu sediaan pembersih daerah kewanitaan berbentuk cair yang dibuat dari bahan dasar dan digunakan untuk membersihkan daerah kewanitaan tanpa menimbulkan iritasi pada kulit. Kulit buah durian mengandung senyawa fenolik, flavonoid, saponin, dan tanin yang dapat digunakan sebagai antijamur. Penelitian ini bertujuan untuk memformulasi sabun pembersih kwanitaan dari ekstrak kulit buah durian. Jenis penelitian ini adalah eksperimen, dilakukan ekstraksi kulit buah durian secara maserasi menggunakan pelarut etanol $96 \%$, dan dipekatkan menggunakan rotary evaporator. Formula sabun pembersih kewanitaan dibuat pada konsentrasi $25 \%$ diantaranya formula A, $\mathrm{B}$, dan $\mathrm{C}$ dengan konsentrasi asam stearat
\end{abstract}

$7,5 \%, 8 \%$, dan $8,5 \%$, dan diuji evaluasi fisik yang meliputi uji organoleptik, homogenitas, $\mathrm{pH}$, tinggi busa, dan uji iritasi. Hasil penelitian menunjukkan bahwa sabun pembersih kewanitaan (feminine hygiene) dari ekstrak kulit buah durian (Durio zibethinus Murray) telah memenuhi syarat uji evaluasi fisik yang stabil yang meliputi uji organoleptik, homogenitas, $\mathrm{pH}$, tinggi busa, dan uji iritasi.

Kata kunci : Ekstrak kulit buah durian, sabun pembersih kewanitaan, evaluasi fisik

Penulis korespondensi :

Eny Nurhikma

Akademi Farmasi Bina Husada Kendari enynurkihima@gmail.com

\section{PENDAHULUAN}

Salah satu upaya kesehatan yang perlu diperhatikan adalah kesehatan reproduksi. Kesehatan reproduksi yaitu keadaan sejahtera fisik, mental dan sosial yang utuh yang tidak semata-mata bebas dari penyakit, dalam semua hal yang berkaitan dengan sistem reproduksi, serta fungsi dan prosesnya. Sistem reproduksi wanita seperti vagina merupakan daerah yang penting untuk dirawat 
dan butuh perhatian ekstra karena letaknya yang tertutup. Banyak dampak yang ditimbulkan apabila seorang wanita tidak memperhatikan kebersihan daerah genitalnya. Diantaranya adalah infeksi yang disebabkan oleh jamur, bakteri, parasit, dan virus seperti keputihan, bau tidak sedap dan lain-lain (Manan, 2011).

Untuk mencegah terjadinya infeksi oleh jamur terhadap vagina, digunakanlah senyawa antijamur. Senyawa antijamur yang berasal dari tanaman sebagian besar diketahui merupakan metabolit sekunder tanaman, terutama golongan fenolik dan terpen dalam minyak atsiri. Berdasarkan penelitian Pratiwi menyebutkan bahwa senyawa fitokimia seperti alkaloid, saponin, tanin, fenolik, flavonoid, dan triterpenoid dapat berkhasiat sebagai antijamur.

Durian merupakan salah satu tanaman yang mengandung fitokimia. Kulit buah durian mengandung senyawa fenolik, flavonoid, saponin, dan tanin. Hal ini menunjukkan bahwa ekstrak kulit buah durian dapat digunakan sebagai antijamur (Hanny, 2015).

Penelitian Hanny, dkk (2015) pada uji daya hambat ekstrak kulit buah durian terhadap jamur Candida albicans dengan konsentrasi $15 \%$, 20\%, dan 25\% dapat menghambat pertumbuhan jamur candida albicans. Hal ini menunjukkan bahwa konsentrasi ekstrak 25\% memiliki daya hambat paling optimal terhadap Candida albicans.

Sabun pembersih kewanitaan (feminine hygiene) adalah suatu sediaan pembersih daerah kewanitaan berbentuk cair yang dibuat dari bahan dasar dan digunakan untuk membersihkan daerah kewanitaan tanpa menimbulkan iritasi pada kulit(Manan, 2011).

\section{METODOLOGI}

\section{Alat dan Bahan}

Batang pengaduk, cawan krus, cawan porselen, corong, gelas kimia, gelas ukur, hot plate, 
lumpang dan alu, pipet tetes, sendok tanduk, seperangkat,alat maserasi, timbangan analitik dan digital, toples, vakum, dan rotavapor.

Aquadest, asam stearat, adeps lanae, ekstrak kulit buah durian, gliserol, minyak vanila, dan triethanolamin.

\section{METODOLOGI}

Alat dan Bahan
Batang pengaduk, cawan krus, cawan porselen, corong, gelas kimia, gelas ukur, hot plate, lumpang dan alu, pipet tetes, sendok tanduk, seperangkat,alat maserasi, timbangan analitik dan digital, toples, vakum, dan rotavapor.

Aquadest, asam stearat, adeps lanae, ekstrak kulit buah durian, gliserol, minyak vanila, dan triethanolamin.

\section{Tabel 1. Formula}

Tiap $100 \mathrm{~mL}$ mengandung :

\begin{tabular}{|c|c|c|c|c|c|}
\hline \multirow{2}{*}{ Bahan } & \multicolumn{3}{|c|}{ Formula $(\%)$} & \multirow{2}{*}{ Kegunaan } & \multirow{2}{*}{ Konsentrasi } \\
\hline & A & B & $\mathrm{C}$ & & \\
\hline Ekstrak kulit buah durian & 25 & 25 & 25 & Bahan aktif & $\begin{array}{l}25 \% \quad \text { (hanny, } \\
2015)\end{array}$ \\
\hline Asam stearat & 7,5 & 8 & 8,5 & Pengemulsi & $\begin{array}{ll}1-20 \% & \text { (rowe, } \\
2009) & \end{array}$ \\
\hline Adeps lanae & 1 & 1 & 1 & $\begin{array}{l}\text { Pembentuk } \\
\text { sabun }\end{array}$ & $\begin{array}{l}0,5-1 \% \\
\text { (anggraini, } \\
2012 \text { ) }\end{array}$ \\
\hline Triethanolamin & 2 & 2 & 2 & Pengemulsi & $\begin{array}{l}2-4 \% \\
2009)\end{array}$ \\
\hline Gliserol & 5 & 5 & 5 & Humektan & $\begin{array}{l}5-15 \% \text { (rowe, } \\
2009 \text { ) }\end{array}$ \\
\hline Minyak vanila & qs & qs & qs & Pengaroma & - \\
\hline Aquadest & ad 100 & ad 100 & ad 100 & Pelarut & - \\
\hline
\end{tabular}

Pembuatan sabun cair pembersih kewanitaan (Feminine Hygiene) Fase minyak (asam stearat dan adeps lanae) dipanaskan sampai suhu $70^{\circ}$ diatas hot plate. Fase air (gliserol dan triethanolamin) juga dipanaskanpada suhu yang sama. Setelahitu dimasukkan fase minyak dan fase air kedalam lumpang secara bersamaan sambil digerus sampai homogen. Aquades 
ditambahkan sedikit demi sedikit sambil terus digerus. Terakhir ditambahkan dengan ekstrak kulit buah durian, minyak vanila dan diaduk sampai homogen kemudian cukupkan volumenya dengan aquades sampai $100 \mathrm{~mL}$.

\section{Uji Evaluasi Fisik Sediaan} Pengamatan Perubahan Bentuk, Warna Dan Bau (Organoleptik)

Pemeriksaan organoleptik dilakukan dengan mendeskripsikan warna, bau, dan bentuk dari sediaan sabun cair, sediaan yang dihasilkan sebaiknya memiliki warna yang menarik, bau yang menyenangkan, dan kekentalan yang cukup agar nyaman dalam penggunaan.

\section{Pemeriksaan pH}

Pemeriksaan $\mathrm{pH}$ dilakukan pada sediaan sabun pembersih kewanitaan (feminine hygiene) selama masa penyimpanan 4 minggu. Pengukuran ph menggunakan $\mathrm{pH}$ meter yang dilakukan dengan pengkalibrasian alat $\mathrm{pH}$ meter menggunakan larutan dapar $\mathrm{pH} 7$ dan $\mathrm{pH} 4$.

\section{Pemeriksaan Homogenitas}

Pemeriksaan homogenitas dilakukan dengan cara sediaan diletakkan diatas kaca arloji, lalu diraba dan diperhatikan secara seksama apakah terdapat butiran kasar pada sediaan.

\section{Uji Tinggi Busa}

Uji tinggi busa dilakukan dengan cara sediaan sabun pembersih kewanitaan (feminine hygiene) sebanyak $1 \mathrm{~g}$ dilarutkan dengan aquadest sebanyak $10 \mathrm{~mL}$ kemudian kocok engan kecepatan konstan selama 20 detik.

\section{Uji Iritasi}

Dilakukan untuk menentukan potensi iritasi pada kulit setelah diberikan sabun peembersih kewanitaan (feminine hygiene), dilakukan dengan cara mengoleskan sediaan pada kulit normalpanel manusia dengan maksud untuk mengetahui apakah sediaan tersebut dapat menumbulkan iritasi pada kulit atau tidak. 


\section{HASIL DAN PEMBAHASAN}

Penelitian ini merupakan penelitian eksperimen berupa formulasi sediaan sabun pembersih kewanitaan (feminine hygiene) dari ekstrak kulit buah durian (Durio zibethinus Murray). Dalam formulasi ini sampel yang digunakan adalah ekstrak kulit buah durian, dimana sampel diambil dari pasar tradisional kota Kendari. Ekstrak kulit buah durian mengandung senyawa fenolik, flavonoid, saponin, dan tanin yang dapat digunakan sebagai antijamur.

Dalam penelitian ini, ekstraksi kulit buah durian menggunakan metode ekstraksi secara maserasi. Ekstraksi adalah penarikan kandungan kimia yang dapat larut sehingga terpisah dari bahan yang tidak dapat larut dengan menggunakan suatu pelarut cair (Ditjen POM, 2010). Kulit buah durian yang dimaksudkan adalah kulit buah durian yang berwarna putih. Pengekstraksian kulit buah durian dalam penelitian ini menggunakan pelarut etanol $96 \%$ dan dilakukan selama $5 \quad x \quad 24$ jam dengan pengadukan satu kali sehari bertujuan untuk mengurangi terjadinya penguapan. Dari hasil ekstraksi tersebut akan diperoleh suatu bentuk ekstrak cair yang kemudian diuapkan dengan menggunakan alat rotary evaporator pada temperatur $\pm 50^{\circ} \mathrm{C}$ sehingga dihasilkan ekstrak kental yang akan dijadikan sebagai zat aktif dalam sediaan.

Dalam pembuatan sabun pembersih kewanitaan (feminine hygiene) ini konsentrasi zat aktif yang digunakan adalah $25 \%$. Alasannya ekstrak kulit buah durian baik digunakan pada konsentrasi 25\% karena memiliki diameter zona hambat terbesar pada candida albicans dibanding dengan konsentrasi $15 \%$ dan 20\% (Hanny, 2010). Pada prosesnya sabun pembersih kewanitaan (feminine hygiene) ini juga ditambahkan bahan tambahan, zatzat tambahan berupa asam stearat 
dan triethanolamin sebagai bahan pengemulsi, adeps lanae sebagai pembentuk sabun, gliserol sebagai humektan (pelembut), oleum vanilla sebagai pengaroma, dan aquadest sebagai pelarut.

Sabun

pembersih

kewanitaan (feminine hygiene) ini merupakan jenis sediaan kosmetik yang dapat dibuat dalam bentuk emulsi. Emulsi adalah campuran bahan yang saling tidak tercampur antara 2 fase, yaitu minyak dan air yang akan tercampur dengan penambahan emulgator. Dan untuk mengetahui mutu sediaan ini perlu dilakukan 5 pengujian antara lain uji organoleptik, uji $\mathrm{pH}$ sediaan, uji homogenitas, uji tinggi busa, dan uji iritasi.

\section{Uji Organoleptik}

Tabel 2. Hasil Pengujian Organoleptik Dari Sediaan Sabun Pembersih Kewanitaan (Feminine Hygiene).

\begin{tabular}{|c|c|c|c|c|c|}
\hline \multirow{2}{*}{ Pemeriksaan } & \multirow{2}{*}{ Formula } & \multicolumn{4}{|c|}{ Pengamatan (minggu ke) } \\
\hline & & I & II & III & IV \\
\hline \multirow{3}{*}{ Warna } & A & Kecoklatan & Kecoklatan & Kecoklatan & Kecoklatan \\
\hline & $\mathrm{B}$ & Kecoklatan & Kecoklatan & Kecoklatan & Kecoklatan \\
\hline & $\mathrm{C}$ & Kecoklatan & Kecoklatan & Kecoklatan & Kecoklatan \\
\hline \multirow{3}{*}{ Bau } & A & $\begin{array}{c}\text { Bau khas } \\
\text { minyak } \\
\text { vanilla }\end{array}$ & $\begin{array}{l}\text { Bau khas } \\
\text { minyak } \\
\text { vanilla }\end{array}$ & $\begin{array}{l}\text { Bau khas } \\
\text { minyak } \\
\text { vanilla }\end{array}$ & $\begin{array}{l}\text { Bau khas } \\
\text { minyak } \\
\text { vanilla }\end{array}$ \\
\hline & B & $\begin{array}{l}\text { Bau khas } \\
\text { minyak } \\
\text { vanilla }\end{array}$ & $\begin{array}{l}\text { Bau khas } \\
\text { minyak } \\
\text { vanilla }\end{array}$ & $\begin{array}{l}\text { Bau khas } \\
\text { minyak } \\
\text { vanilla }\end{array}$ & $\begin{array}{l}\text { Bau khas } \\
\text { minyak } \\
\text { vanilla }\end{array}$ \\
\hline & $\mathrm{C}$ & $\begin{array}{c}\text { Bau khas } \\
\text { minyak } \\
\text { vanilla } \\
\end{array}$ & $\begin{array}{l}\text { Bau khas } \\
\text { minyak } \\
\text { vanilla } \\
\end{array}$ & $\begin{array}{c}\text { Bau khas } \\
\text { minyak } \\
\text { vanilla } \\
\end{array}$ & $\begin{array}{l}\text { Bau khas } \\
\text { minyak } \\
\text { vanilla } \\
\end{array}$ \\
\hline \multirow{3}{*}{ Bentuk } & $\mathrm{A}$ & Cair & Cair & Cair & Cair \\
\hline & B & Kental & Kental & Kental & Kental \\
\hline & $\mathrm{C}$ & Kental & Kental & Kental & Kental \\
\hline
\end{tabular}

\section{Keterangan :}

Formula A : Konsentrasi Asam Stearat 7,5\%

Formula B : Konsentrasi Asam Stearat 8\%

Formula C : Konsentrasi Asam Stearat 8,5\% 
Berdasarkan hasil formula A, B, dan C menunjukkan pengamatan penelitian dari bentuk, bau dan warna sediaan minggu pertama hingga minggu stabil selama 4 minggu keempat pada uji organoleptik penyimpanan.

\section{Uji Homogenitas}

Tabel 3. Data Hasil Pengukuran pH Dari Sediaan Sabun Pembersih Kewanitaan (Feminine Hygiene).

\begin{tabular}{ccccc}
\hline \multirow{2}{*}{ Formula } & \multicolumn{4}{c}{ Pengamatan (Minggu Ke) } \\
\cline { 2 - 5 } & I & II & III & IV \\
\hline A & 7,62 & 7,39 & 8,08 & 7,48 \\
\hline B & 7,58 & 7,51 & 7,92 & 7,39 \\
\hline C & 7,56 & 7,48 & 7,98 & 7,46 \\
\hline
\end{tabular}

Hasil pengamatan perubahan $\mathrm{pH}$ juga bisa menunjukkan adanya penaikan $\mathrm{pH}$ disebabkan oleh perubahan kimia yang kecil, hal ini disebabkan zat aktif maupun zat tambahan karena suhu $\mathrm{pH}$ meter pada tiap dalam sediaan pada kondisi pengukuran $\mathrm{pH}$ sediaan untuk penyimpanan karena pengaruh masing-masing formula tidak pembawa atau lingkungan. konstan atau suhu tidak sama,

\section{Uji Homogenitas}

Tabel 4. Data Hasil Pengujian Homogenitas Dari Sediaan Sabun Pembersih Kewanitaan (Feminine Hygiene).

\begin{tabular}{ccccc}
\hline \multirow{2}{*}{ Formula } & \multicolumn{4}{c}{ Pengamatan (Minggu Ke) } \\
\cline { 2 - 5 } & I & II & III & IV \\
\hline A & Homogen & Homogen & Homogen & Homogen \\
\hline B & Homogen & Homogen & Homogen & Homogen \\
\hline C & Homogen & Homogen & Homogen & Homogen \\
\hline
\end{tabular}


Hasil pemeriksaan homogenitas sediaan yang dilakukan dari minggu pertama hingga keempat menunjukkan bahwa tidak adanya partikel pada sediaan sabun pembersih kewanitaan (feminine hygiene) baik formula A, B, maupun C. Berdasarkan penelitian Hanny (2015) menyatakan bahwa sifat zat aktif dari ekstrak kulit buah durian yaitu saponin, flavonoid, dan tanin mudah tercampur dengan basis tipe minyak-air sehingga tidak terjadi penggumpalan atau pemisahan fase. Hal ini menunjukkan bahwa sediaan sabun pembersih kewanitaan (feminine hygiene) memenuhi syarat homogenitas.

\section{Uji Tinggi Busa}

Tabel 5. Data Hasil pengujian Tinggi Busa Dari Sediaan Sabun Pembersih Kewanitaan (Feminine Hygiene).

\begin{tabular}{ccccc}
\hline \multirow{2}{*}{ Formula } & \multicolumn{4}{c}{ Pengamatan (Minggu Ke) } \\
\cline { 2 - 5 } & I & II & III & IV \\
\hline A & I cm & $1 \mathrm{~cm}$ & $1 \mathrm{~cm}$ & $1 \mathrm{~cm}$ \\
\hline B & $0,5 \mathrm{~cm}$ & $0,5 \mathrm{~cm}$ & $0,5 \mathrm{~cm}$ & $1 \mathrm{~cm}$ \\
\hline C & $0,5 \mathrm{~cm}$ & $0,5 \mathrm{~cm}$ & $0,5 \mathrm{~cm}$ & $1 \mathrm{~cm}$ \\
\hline
\end{tabular}

Berdasarkan tabel 9 suatu produk karena tinggi busa menunjukkan bahwa hasil tidak menunjukkan kemampuan pengukuran tinggi busa dalam air dalam membersihkan. Hal ini suling menunjukkan tidak adanya dikaitkan pada nilai estetika yang perbedaan yang signifikan dari disukai konsumen. Tetapi untuk minggu pertama hingga minggu sabun pembersih kewanitaan keempat, hasil yang diperoleh (femininehygiene) tidak boleh tinggi tinggi busa berkisar antara 0,5 cm - atau busa harus rendah (Anggraini, $1 \mathrm{~cm}$. Tidak ada syarat tinggi busa 2012).

minimum atau maksimum untuk 


\section{Uji Iritasi}

Tabel 6. Data Hasil Pengujian Iritasi Dari Sediaan Sabun Pembersih Kewanitaan (Feminine Hygiene).

\begin{tabular}{ccccc}
\hline \multirow{2}{*}{ Formula } & \multicolumn{4}{c}{ Pengamatan (Minggu Ke) } \\
\cline { 2 - 5 } & I & II & III & IV \\
\hline \multirow{2}{*}{ A } & Tidak & Tidak & Tidak & Tidak \\
& mengiritasi & mengiritasi & mengiritasi & mengiritasi \\
\hline \multirow{2}{*}{ B } & Tidak & Tidak & Tidak & Tidak \\
& mengiritasi & mengiritasi & mengiritasi & mengiritasi \\
\hline \multirow{2}{*}{ C } & Tidak & Tidak & Tidak & Tidak \\
& mengiritasi & mengiritasi & mengiritasi & mengiritasi \\
\hline
\end{tabular}

Hasil pengujian menyatakan bahwa sediaan sabun pembersih kewanitaan (feminine hygiene) formula A, B, dan C yang ditandai dengan tidak adanya edema dan eritema pada kulit (Tabel.10) sehingga dapat dinyatakan bahwa sabun pembersih kewanitaan (feminine hygiene) tidak mengiritasi pada kulit. Eritema adalah warna

\section{KESIMPULAN}

Ekstrak kulit buah durian dapat dibuat atau diformulasikan menjadi sediaan sabun pembersih kewanitaan (feminine hygiene) dengan variasi konsentrasi asam stearat $7,5 \%, 8 \%$, dan $8,5 \%$, dan memenuhi syarat evaluasi fisik sediaan untuk formula B dan C. merah pada kulit yang disebabkan oleh pembesaran pembuluh kapiler yang terjadi akibat alergi, sedangkan Edema adalah akumulasi abnormal cairan didalam ruang interstitial (celah diantara sel) atau jaringan tubuh yang menimbulkan pembengkakan (Budimulja, 2007).

\section{DAFTAR PUSTAKA}

Anggraini. 2012. Formulasi Sabun Cair dari Ekstrak Batang Nanas (Ananas comosus L) Untuk Mengatasi Jamur Candida Albicans. Padang : STIFA Riau.

Hanny, Dkk. 2015. Krim Kulit Buah Durian (Durio zibethinus L.) Sebagai Obat Herbal Pengobatan Infeksi Jamur Candida Albicans. Semarang : Sekolah Tinggi Ilmu Farmasi.

Manan, El. 2011. Miss V. Yogyakarta : Buku Biru.

Pratiwi, Suthanty Ika. 2008. Aktivitas Antibakteri Tepung Daun Jarak (Jatropha curcas L.) pada Berbagai 
Bakteri Saluran Pencernaan Ayam Broiler Secara in vitro. Bogor: ITB.

Rowe, C.R., Paul, J.S., dan Marian, E.Q. 2009. Handbook of Pharmaceutical Excipients. Edisi Keenam. Washington : Pharmaceutical Press. 